\title{
Utilization of Agricultural By-Products for Alpha- Amylase Production under Solid State Fermentation by Bacillus subtilis
}

\author{
Huzairy Hassan ${ }^{1}$ and Khairiah Abd. Karim ${ }^{2, *}$ \\ 1 School of Bioprocess Engineering, Universiti Malaysia Perlis, Kompleks Pusat Pengajian Jejawi 3, 02600 \\ Arau, Perlis, Malaysia \\ 2 School of Chemical Engineering, Universiti Sains Malaysia Engineering Campus, 14300 Nibong Tebal, \\ Penang, Malaysia \\ * E-mail: chkhairiah@eng.usm.my
}

\begin{abstract}
The production of alpha-amylase by Bacillus subtilis was investigated under different cultivation conditions on two different solid substrates as the support, i.e. oil palm empty fruit bunch (OPEFB) fibers and rice straw using solid state fermentation (SSF) process. Both solid substrates were first pre-treated using $\mathrm{NaOH}$ to remove lignin and silica and to break down the hemicellulose structures. The influences of incubation time, incubation temperature and the additional carbon and nitrogen sources on the production of alpha-amylase by B. subtilis were investigated. After $48 \mathrm{~h}$ of incubation, the highest enzyme activities were obtained at $39.9 \mathrm{U} / \mathrm{g}$ and $23.5 \mathrm{U} / \mathrm{g}$ for rice straw and OPEFB fibers, respectively. The optimum temperature for alpha-amylase production was observed at $45^{\circ} \mathrm{C}$ for the $\mathrm{OPEFB}$ fibers and $55^{\circ} \mathrm{C}$ for the rice straw. Among the defined carbohydrates, the addition of glucose $(0.02 \mathrm{~g} / \mathrm{g}$ dry substrate $)$ has significantly improved the production of alpha-amylase. Similar effect was observed when yeast extract $(0.01$ $\mathrm{g} / \mathrm{g}$ dry substrate) was supplemented as the additional nitrogen source. Rice straw appeared to be the best solid substrate in producing alpha-amylase $(276 \mathrm{U} / \mathrm{g})$ in SSF under these optimum cultivation conditions.
\end{abstract}

Keywords: Agricultural by-products, alpha-amylase, solid state fermentation, Bacillus subtilis.

ENGINEERING JOURNAL Volume 16 Issue 5

Received 20 February 2012

Accepted 18 July 2012

Published 1 October 2012

Online at http://www.engj.org/

DOI:10.4186/ej.2012.16.5.177 


\section{Introduction}

Malaysia has many resources with very high production of agricultural products annually, including rice, palm oil, sugar canes, corns, and rubbers. Along with the millions of tonnes of agricultural production yearly, the by-products (wastes) are also generated abundantly. For example, Malaysia as the largest producer of palm oil in the world with 4.2 million hectares of oil palm plantations, generates about 90 million tonnes of renewable biomass (trunks, fronds, shells, palm press fibers and the empty fruit bunches) each year [1]. From this total, the empty fruit bunches (EFB) represent about $9 \%$, which is equivalent to about 8.1 million tonnes of EFB. Paddy rice production also yields abundant of by-products (rice husk and rice straw) from time to time. Oil Palm Empty Fruit Bunch (OPEFB) fibers and rice straw are known to compose of relatively high cellulosic materials and various nutrients. These features make the two agricultural wastes very suitable substrates or supports in various fermentation processes especially for solid-state type fermentation using microorganisms.

There are a number of researches and projects that utilized such agricultural feedstock in various fields of productions, for instance; bio-fuels, commodities or chemicals, enzymes, biopharmaceuticals and food. From these valuable products, enzymes are among the largest production especially for food, pharmaceuticals, detergents and textile industries. Enzymes are very important compounds because they function mainly as catalysts in biological and chemical processes. An enzyme helps in bringing a catalyzedreaction to its equilibrium position more quickly than that would occurs otherwise [2]. Therefore, less energy is required to undertake the reaction as it can be achieved faster. Subsequently, the production cost could also be reduced. One of the widely studied and produced enzymes is alpha-amylase, which is important for food industry, alcoholic compounds production, textile and paper industry [3]. It is found that alpha-amylase can almost completely replace chemical hydrolysis of starch in the starch-processing industry [4]. Alpha-amylase is mainly produced by a bacterium which comes from the Bacillus species or a fungus from Aspergillus species.

Most researchers nowadays shift their work to producing various enzymes from biomaterials or natural by-products which are mainly obtained from agricultural industries. This is owing to the fact that the researchers are dedicated to significantly reducing the usage of chemicals which are normally hazardous to humans, animals, plants and particularly the environment. Therefore, in order to wisely utilize the agricultural wastes with less negative impact to the environment, the OPEFB fibers and rice straw are very good choices to be used as raw materials in the production of high value added products especially alphaamylase enzymes.

The aim of this study was to evaluate the feasibility of OPEFB fibers and rice straw as solid substrates for alpha-amylase production and to optimize the effect of incubation time, incubation temperature, additional carbon and nitrogen sources on the production of alpha-amylase by B. subtilis using SSF on pretreated OPEFB fibers and rice straw.

\section{Experimental}

\subsection{Solid Substrates Preparation}

OPEFB fibers were collected from the palm oil mill, United Oil Palm Industries Sdn Bhd, Nibong Tebal, Pulau Pinang. The fibers were washed with distilled water and dried at $45-50^{\circ} \mathrm{C}$ for $24 \mathrm{~h}$. Then the OPEFB fibers were ground $(1-2 \mathrm{~mm})$ and kept in a dry place. The whole form of rice straws were collected from Kampung Tok Pulau, Perlis. The collected rice straws were soaked in distilled water and washed to remove soils attached to them. They were dried in an oven at $45-50^{\circ} \mathrm{C}$. The dried rice straws were cut into small pieces of about $1-2 \mathrm{~cm}$ long prior to pre-treatment with alkali to form fibers.

\subsection{Pre-treatment}

The delignification procedures of OPEFB fibers and rice straws were adopted from Chang et al. (1998) [5] with slight modification. The solid substrates were soaked in $2.0 \%(\mathrm{w} / \mathrm{v}) \mathrm{NaOH}$ solution and heated at $86^{\circ} \mathrm{C}$ for $3 \mathrm{~h}$. These treated substrates were filtered and washed with distilled water until no traces of alkali could be detected and dried in an oven at $60^{\circ} \mathrm{C}$ for 2 days. The treated OPEFB and rice straw fibers were then designated as dry substrate. 


\subsection{Microorganism}

B. subtilis used in this study was obtained from the Bioprocess Laboratory of the School of Bioprocess Engineering, Universiti Malaysia Perlis (UniMAP). The culture was maintained and sub-cultured on nutrient agar and was stored at $4^{\circ} \mathrm{C}$.

\subsection{Inoculum Preparation and Batch Experiment of SSF}

The nutrient broth was prepared in a $250 \mathrm{~mL}$ Erlenmeyer flask. The culture B. subtilis was inoculated in 100 $\mathrm{mL}$ nutrient broth for 8 hours of optimum growth at $32^{\circ} \mathrm{C}$ and $150 \mathrm{rpm}$. The inoculated broth $(10 \mathrm{~mL})$ was centrifuged at $4000 \mathrm{rpm}$ for 10 minutes. The cell pellet was re-suspended with $5 \mathrm{~mL}$ sterile distilled water and added to the $250 \mathrm{~mL}$ Erlenmeyer flasks containing $4 \mathrm{~g}$ pre-treated OPEFB fibers. The fermentation medium $(10 \mathrm{~mL})$ is comprised of $\mathrm{MgSO}_{4} .7 \mathrm{H}_{2} \mathrm{O}(0.2 \mathrm{~g} / \mathrm{L}), \mathrm{CaCl}_{2}(0.02 \mathrm{~g} / \mathrm{L}), \mathrm{KH}_{2} \mathrm{PO}_{4}(1.0 \mathrm{~g} / \mathrm{L}), \mathrm{NH}_{3} \mathrm{H}_{2} \mathrm{PO}_{4}$ $(1.0 \mathrm{~g} / \mathrm{L}), \mathrm{NH}_{4} \mathrm{NO}_{3}(1.0 \mathrm{~g} / \mathrm{L})$ and $\mathrm{FeCl}_{3}(0.05 \mathrm{~g} / \mathrm{L})$ was evenly mixed with the OPEFB fibers and cells. The initial $\mathrm{pH}$ of fermentation media was maintained throughout the experiments at $\mathrm{pH}$ 7. The same procedures were followed for the rice straw. Each experiment of SSF was carried out in duplicate sets. These sets of experiment were categorized as control experiments.

\subsection{Optimization of Process Parameters}

The various process parameters that influence the production of alpha-amylase during SSF were optimized. In a sequential order, the following parameters were studied: incubation time $(24-120 \mathrm{~h})$, incubation temperature $\left(35-65^{\circ} \mathrm{C}\right)$, additional carbon sources $(0.02 \mathrm{~g} / \mathrm{g}$ dry substrate) (glucose, xylose, fructose, sucrose and maltose), and nitrogen sources $(0.01 \mathrm{~g} / \mathrm{g}$ dry substrate) (sodium nitrate, ammonium sulfate, yeast extract and urea).

\subsection{Enzyme Extraction}

Enzyme alpha-amylase was extracted by mixing $50 \mathrm{~mL}$ of $0.1 \mathrm{M}$ phosphate buffer $(\mathrm{pH}$ 7) with the whole solid substrates and the mixture was shaken on a rotary shaker at $250 \mathrm{rpm}$ for 30 minutes. The buffer containing enzyme was separated from the solid substrates through filter paper. The filtrate was centrifuged at $4000 \mathrm{rpm}$ for 20 minutes. The clear brown supernatant was used as the enzyme source for the enzyme assay analysis.

\subsection{Enzyme Assays}

Alpha-amylase activity was determined by the procedure of Bernfeld (1955) [6] using soluble starch as a substrate. One unit $(\mathrm{U})$ of alpha-amylase activity was defined as the amount of enzyme that releases $1 \mu \mathrm{mol}$ of reducing sugars as glucose per minute, under assay conditions of $\mathrm{pH} 7$ and incubation temperature of $37^{\circ} \mathrm{C}$ with phosphate buffer solution. The enzyme activity was expressed in $\mathrm{U} / \mathrm{g}$ of dry substrate.

\section{Results and Discussion}

\subsection{Effect of incubation time on alpha-amylase production}

The optimum incubation time with the highest alpha-amylase activities for both substrates (39.9 and 23.5 $\mathrm{U} / \mathrm{g}$ for the rice straw and OPEFB fibers, respectively) was achieved after $48 \mathrm{~h}$ (Fig. 1). The alpha-amylase production has declined significantly after $81 \mathrm{~h}$ and reached the minimum level after $120 \mathrm{~h}$ when rice straw was used as the substrate. This shows that further increase in incubation time led to a significant reduction in enzyme activity. The decline in enzyme activity might be due to denaturation and/or decomposition of alpha-amylase as a result of interactions with other compounds in the fermentation medium [7]. Another possible reason is due to the presence of some inhibitors that might inhibit the enzyme secretion. For instance, manganese $(\mathrm{Mn})$ which contains in OPEFB fibers [8] may reduce the production of the enzyme 
and copper $(\mathrm{Cu})$ may be poisonous to the enzyme secretion [9]. The presence of these metals might affect the stability of enzyme folding, thus break some portions of protein structure to end up with denaturation of enzyme.

This observation is also in accordance with the findings reported by previous researchers, i.e. optimum time achieved in the range of 48 until $72 \mathrm{~h}$. Ramesh and Lonsane (1991) [10] found that the production of bacterial alpha-amylase using solid-state fermentation technique required less fermentation time $(24-48 \mathrm{~h})$, which leads to considerable reduction in the capital cost and recurring expenditure. Anto et al. (2006) [11] also reported that the highest production of alpha-amylase by B. cereus on the wheat bran and rice wastes substrates was observed after $72 \mathrm{~h}$ and further incubation time would decreased the production of enzyme. The highest production of alpha-amylase by B. licheniformis was observed after $48 \mathrm{~h}$ of incubation [12].

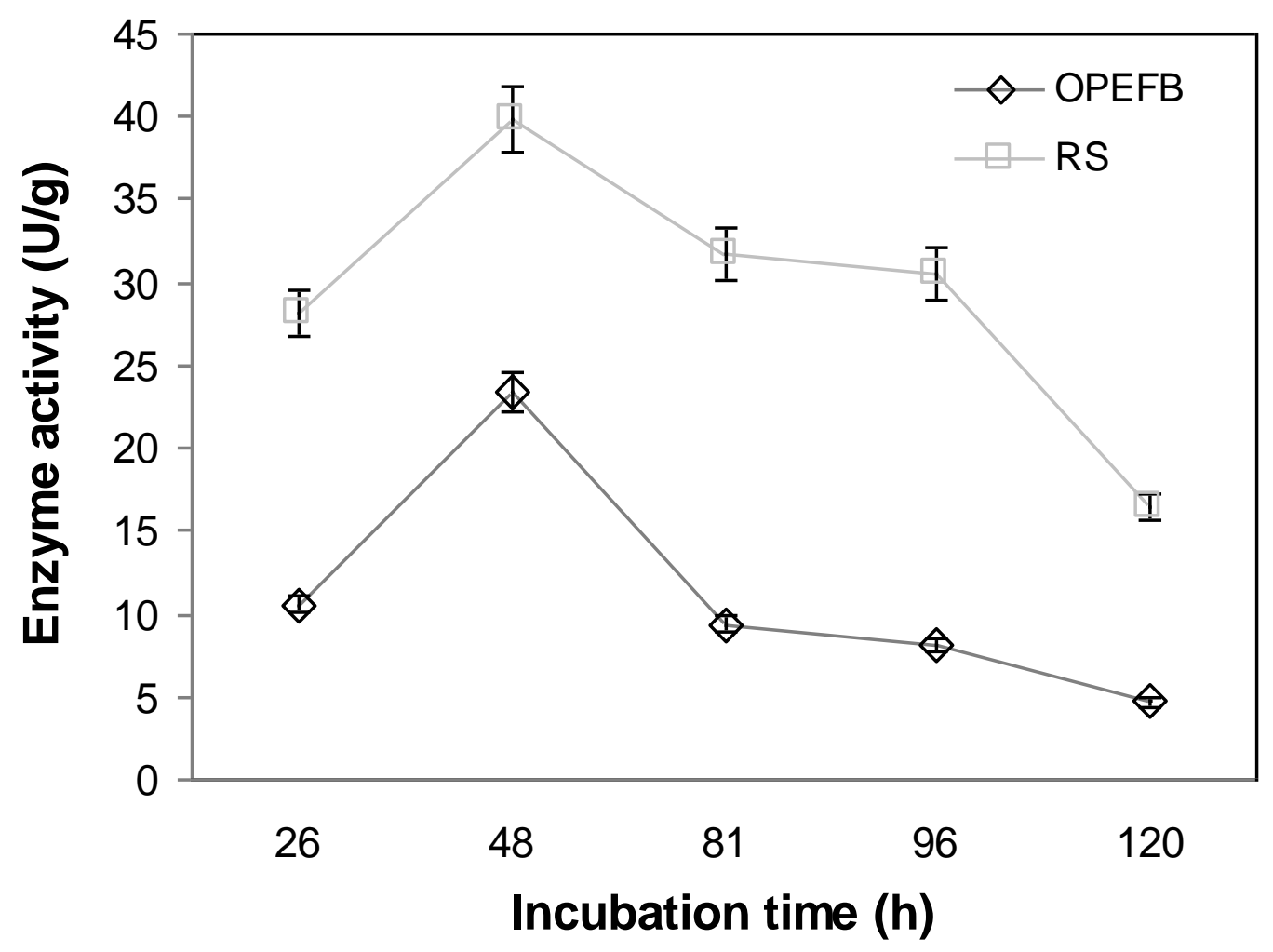

Fig. 1. Effect of incubation time for the optimum production of alpha-amylase. ( $Y$ error bars indicate the standard error from mean value of duplicates.)

\subsection{Effect of Incubation Temperature on Alpha-Amylase Production}

In discussing the effect of incubation temperature for the $\alpha$-amylase production, normally it is much related to the growth of B. subtilis. Therefore, the optimum incubation temperature for the fermentation depends on whether the microorganism is mesophilic or thermophilic [13]. The bacterial $\alpha$-amylase enzyme is produced at much wider range of temperature. A number of studies found that most Bacillus species including B. amyloliquefaciens, B. subtilis, B. licheniformis and B. stearothermophilus produced $\alpha$-amylase at temperature range from 37 till $60^{\circ} \mathrm{C}[14]-[16]$.

In this study, the alpha-amylase produced by B. subtilis showed considerable enzyme activity at the range of $35-65^{\circ} \mathrm{C}$. Figure 2 shows that the enzyme activity increased up to $120 \mathrm{U} / \mathrm{g}$ at $55^{\circ} \mathrm{C}$ and $81 \mathrm{U} / \mathrm{g}$ at $45^{\circ} \mathrm{C}$ by using rice straw and OPEFB fibers, respectively. For the rice straw, the enzyme activity dropped tremendously from $120 \mathrm{U} / \mathrm{g}$ to $24 \mathrm{U} / \mathrm{g}$ at $55^{\circ} \mathrm{C}$ and $65^{\circ} \mathrm{C}$. Nevertheless, there is not much difference in enzyme activity produced by OPEFB fibers as $73 \%$ and $61 \%$ of enzyme activities were observed at $55^{\circ} \mathrm{C}$ and $65^{\circ} \mathrm{C}$, respectively, compared to the optimum temperature at $45^{\circ} \mathrm{C}$. 


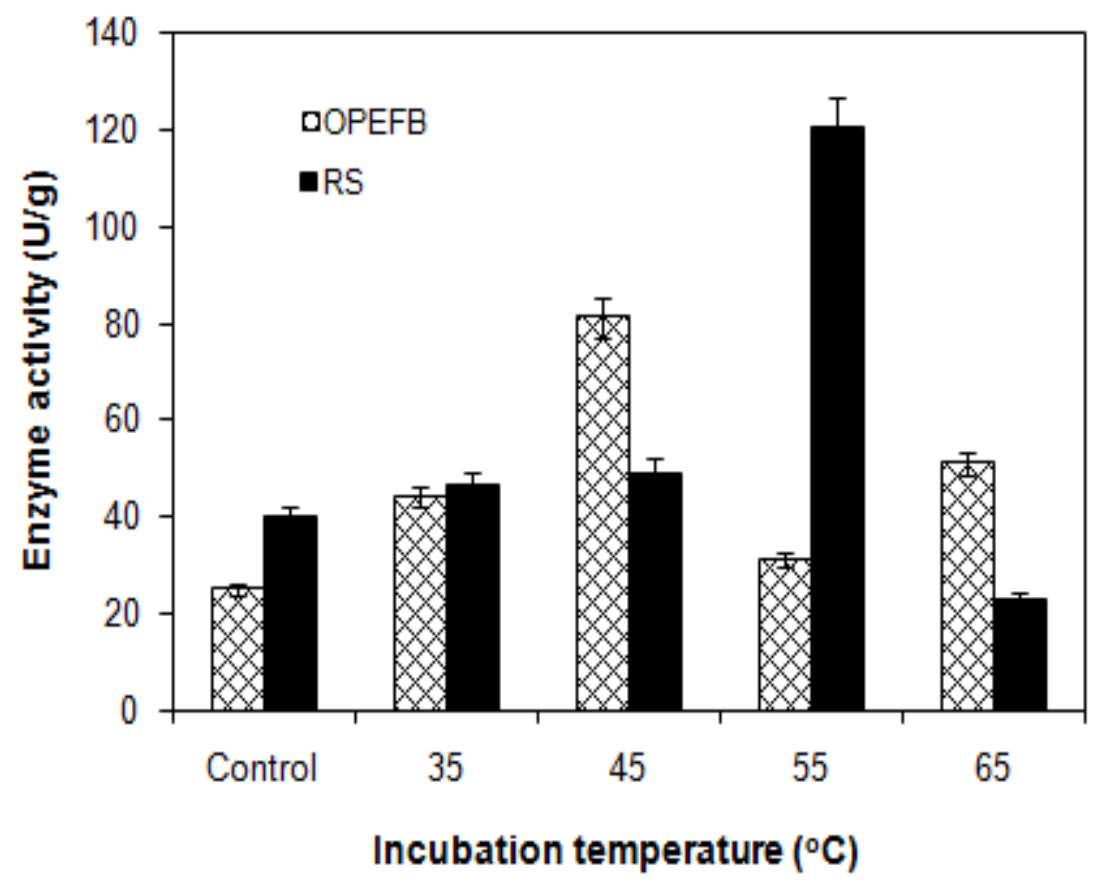

Fig. 2. Effect of incubation temperature for the optimum production of alpha-amylase ( $\mathrm{Y}$ error bars indicate the standard error from mean value of duplicates).

The results achieved from this study demonstrate that B. subtilis used in this study is a thermophilic and thermotolerant bacterium [17] and the alpha-amylase enzyme produced was thermostable at the optimum temperature of $45-55^{\circ} \mathrm{C}$. This can be explained by the presence of $\mathrm{Ca}^{2+}$ and $\mathrm{Mg}^{2+}$ inside the OPEFB fibers [8] which can increase and stabilize the secretion of $\alpha$-amylase by $B$. subtilis especially against enzyme thermal denaturation. On the other hand, for the rice straw, the enzyme activity increased and decreased dramatically at $55-65^{\circ} \mathrm{C}$ of incubation temperature. This is due to the absence or near absence of stability compound such as $\mathrm{Ca}^{2+}$ and $\mathrm{Mg}^{2+}$.

\subsection{Effect of Additional Carbon Sources on Alpha-Amylase Production}

Supplementation of various carbon sources has resulted in enhanced alpha-amylase synthesis by B. subtilis using both dry substrates if compared with the control experiment. Glucose exhibited the highest enzyme activities, i.e. $276 \mathrm{U} / \mathrm{g}$ and $127 \mathrm{U} / \mathrm{g}$ for rice straw and OPEFB fibers, respectively (Fig. 3). The presence of xylose naturally in OPEFB could increase the enzyme activity to $100 \mathrm{U} / \mathrm{g}$ after supplying the external xylose source. In contrast, other carbon sources did not improve alpha-amylase production to a greater extent comparatively to glucose. 


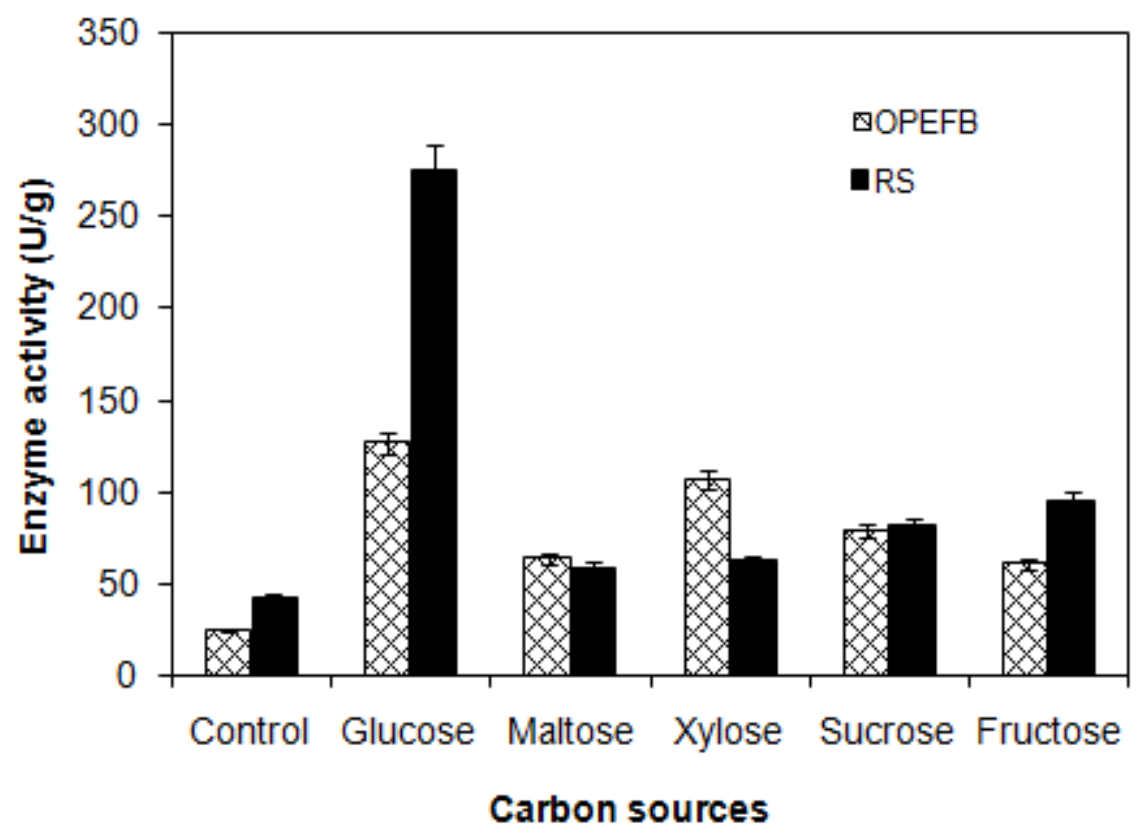

Fig. 3. Effect of additional carbon sources $(0.02 \mathrm{~g} / \mathrm{g}$ dry substrate) for the optimum production of alphaamylase (Y error bars indicate the standard error from mean value of duplicates.)

It is important to emphasize that rice straw itself contains about $20 \%$ starch on a dry weight basis [18], which becomes saccharified to glucose as a result of the action of enzyme elaborated by the culture during the fermentation process. Subsequently, the effective concentration of glucose in the SSF medium will be substantially higher than the value of the supplemented glucose concentration $(0.02 \mathrm{~g}$ glucose $/ \mathrm{g}$ rice straw). The increase in glucose concentration has significantly increased the alpha amylase activity (Fig. 3), indicating the ability of the SSF technique to significantly minimize catabolite repression of alpha-amylase production by B. subtilis.

It was reported that glucose was among the best carbon sources for alpha-amylase production by $B$. cereus and B. thermooleovorans [11], [19]. On the other hand, soluble starch has been found to be the best carbon source for alpha amylase production by B. lincheniformis M27 [10] and B. amyloliquefaciens [19] while fructose supported maximum alpha amylase production in solid state fermentation of B. licheniformis SPT 27 [20]. Inevitably, the result obtained in this study showed that the addition of fructose did not help to improve the production of alpha-amylase by B. subtilis for both dry substrates. These results may infer that different Bacillus sp. require different carbon source for the synthesis of alpha-amylase. In addition, complex sugars like sucrose and maltose are relatively more difficult to be utilized by B. subtilis and required longer time to be decomposed into simpler sugar. Besides, it was found that maltose and lactose did not exert any effect on the B. amyloliquefaciens's activity of enzyme synthesis [20].

From the results on the effect of additional carbon sources, it is apparent that B. subtilis can still produce alpha-amylase by utilizing carbon content that present in the dry substrates (in the control experiment). The additional carbon sources which act as inducer, has enhanced the production of alphaamylase, which is known as an inducible enzyme [20]. The types of saccharide molecules which have 6 or 5 carbon atoms gave mix trends to the production of alpha-amylase. In other words, the utilization of carbon sources by B. subtilis did not give a significant meaning to the types of molecules whether they have 5 or 6 carbon atoms.

\subsection{Effect of Additional Nitrogen Sources on Alpha-Amylase Production}

As depicted in Fig. 4, supplementation of yeast extract (organic nitrogen source) has significantly affected the alpha-amylase production for both substrates $(134.3$ and $85.1 \mathrm{U} / \mathrm{g}$ for rice straws and OPEFB fibers, respectively), followed by urea. However, the addition of ammonium sulfate and sodium nitrate showed inhibitory effect on the enzyme production especially in the fermentation system using rice straw as the dry 
solid substrate. Similar observation was also reported on alpha-amylase production by B. licheniformis SPT 278 [21], where supplementation of peptone (organic nitrogen source) has great influence on alpha amylase production compared to ammonium hydrogen phosphate (inorganic nitrogen source). This result indicates that the organic nitrogen sources, i.e. yeast extract and urea, are favourable than inorganic nitrogen sources including ammonium sulfate and sodium nitrate. This finding is also supported by Bhargav et al. (2008) [22] that the nutrient supplementation from organic sources increases enzyme production to a greater extent than inorganic sources. Yeast extract is classified as undefined media which contain high nutritional amino acids, and compatible nitrogen and carbon sources to support the growth of B. subtilis, in addition to other valuable nutrients that stimulate the enzyme activity.

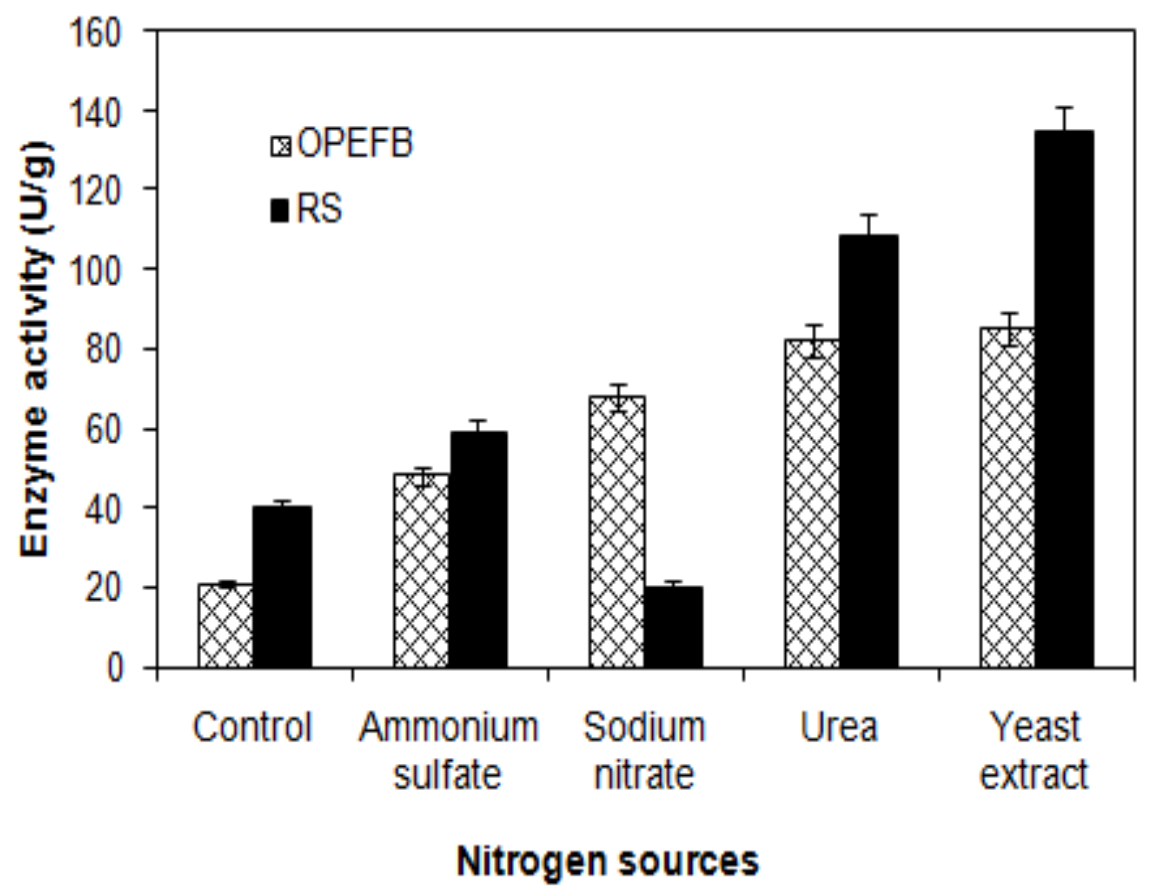

Fig. 4. Effect of additional nitrogen sources $(0.01 \mathrm{~g} / \mathrm{g}$ dry substrate) for the optimum production of alpha-amylase ( $\mathrm{Y}$ error bars indicate the standard error from mean value of duplicates).

It is notable that the addition of sodium nitrate to the rice straw showed negative influence to the production of alpha-amylase but not with the fermentation system utilizing OPEFB fibers as the dry substrate. This result could be supported by the finding of Ramachandran et al. (2004) [23]. The depressing effect to the alpha-amylase production is because of the nitrate $\left(\mathrm{NO}_{3}^{-}\right)$compound that is more difficult to be degraded compared to the ammonium $\left(\mathrm{NH}_{4}{ }^{+}\right)$salt. Nitrate needs to be degraded into a simpler compound of nitrite $\left(\mathrm{NO}_{2}{ }^{-}\right)$and subsequently into ammonium. As in ammonium sulfate, the nitrogen source is readily to be utilized by $B$. subtilis, thus the consumption of nitrogen sources in ammonium sulfate is faster and more effective than that in sodium nitrate (in the case when rice straw was used as the substrate). For the OPEFB fibers on the other hands, the enzyme activity increased by about $50 \%$ by supplying sodium nitrate. This is because the supplementation of sodium ions contained in the salts may induce the significant contents of natural sodium inside the OPEFB fibers composition [8] which is about $11.0 \pm 0.4 \mathrm{~g} / \mathrm{g}$ of dry OPEFB. Hence, the supply of sodium nitrate to OPEFB fibers has increased the production of $\alpha$-amylase.

\section{Conclusion}

The results obtained from this study indicated that OPEFB fibers and rice straw were capable to be utilized as the substrate for the production of alpha-amylase by B. subtilis in solid state fermentation process. Rice straw yielded the highest $\alpha$-amylase activity in all studies of effect of incubation time, incubation temperature and additional carbon and nitrogen sources. The highest $\alpha$-amylase enzyme activities of 39.9 
and $23.5 \mathrm{U} / \mathrm{g}$ for the rice straw and OPEFB fibers, respectively, were produced after $48 \mathrm{~h}$ of incubation time. For the results of incubation temperature, OPEFB fibers yielded $81 \mathrm{U} / \mathrm{g}$ enzyme activity at $45^{\circ} \mathrm{C}$, and rice straw yielded $120 \mathrm{U} / \mathrm{g}$ at $55^{\circ} \mathrm{C}$. The additional glucose gave the highest enzyme activities of 275.7 and $126.7 \mathrm{U} / \mathrm{g}$ for rice straw and OPEFB fibers, respectively. In studying the effect of additional nitrogen sources, yeast extract was observed to yield the highest enzyme activities of 134.3 and $85.1 \mathrm{U} / \mathrm{g}$ for rice straw and OPEFB fibers, respectively. As a conclusion, it is inevitable that apart from the potential for large-scale production of industrial enzymes, the utilization of these agricultural by-products will help to solve the pollution problems due to their continuous accumulation and also contribute to safe and economical waste management.

\section{Acknowledgement}

The authors would like to thank Universiti Sains Malaysia for providing the funding and facilities to conduct this research. Huzairy Hassan is grateful to Universiti Malaysia Perlis for the Research Fellowship award.

\section{References}

[1] M. A. Sukiran, C. M. Chin, and N. K. Abu Bakar, "Bio-oils from pyrolysis of oil palm empty fruit bunches," American Journal of Applied Sciences, vol. 6, no. 5, pp. 869-875, 2009.

[2] W. Aehle, Ensymes in Industry: Production and Applications. Wiley-VCH Verlag GmbH \& Co., Netherlands, 2007.

[3] G. Rajagopalan and C. Krishnan, "Optimization of agro-residual medium for $\alpha$-amylase production from a hyper-producing Bacillus subtilis KCC103 in submerged fermentation.," J. Chem. Technol. Biotechnol., vol. 84, pp. $618-625,2009$.

[4] A. Pandey, P. Nigam, V. T. Soccol, D. Singh, and R. Mohan, "Advances in microbial amylases," Biotechnol. Appl. Biochem., vol. 31, pp. 135 - 152, 2000.

[5] V. S. Chang, M. Nagwani, and M. T. Holtzapple, "Lime pre-treatment of crop residues bagasse and wheat straw," Appl. Biochem. Biotechnol., vol. 74, pp. 135-159, 1998.

[6] P. Bernfeld, "Amylases, $\alpha$ and $\beta$," in Methods in Ensymology. New York : Academic Press, 1955.

[7] M. V. Ramesh and B. K. Lonsane, "Solid state fermentation for production of $\alpha$-amylase by Bacillus megaterium 16 M," Biotechnol. Lett., vol. 9, pp. 323-328, 1987.

[8] K. N. Law, W. R. Wan Daud, and A. Ghazali, "Morphology and chemical nature of fiber strands of oil palm empty fruit bunch (OPEFB)," BioResources, vol. 2, no. 3, pp. 351-362, 2007.

[9] B. Atkinson and F. Mavituna, Biochemical Engineering and Biotechnology Handbook. United States: Macmillan Publishers Ltd, 1983.

[10] M. V. Ramesh and B. K. Lonsane, "Regulation of alpha-amylase production in Bacillus licheniformis M27 by enzyme end-products in submerged fermentation and its overcoming in solid state fermentation system," Biotechnol. Lett., vol. 13, pp. 355 - 360, 1991.

[11] H. Anto, U. Trivedi, and K. Patel, "Alpha amylase production by Bacillus cereus MTCC 1305 using solid-state fermentation," Food Technol. Biotechnol., vol. 44, no. 2, pp. 241 - 245, 2006.

[12] I. Haq, H. Ashraf, J. Iqbal, and M. A. Qadeer, "Production of alpha amylase by Bacillus licheniformis using an economical medium," Biores. Technol., vol. 87, pp. 57 - 61, 2003.

[13] S. Sivaramakrishnan, D. Gangadharan, K. M. Nampoothiri, C. R. Soccol, and A. Pandey, " $\alpha$-amylases from microbial sources-An overview on recent developments," Food Technol. Biotechnol., vol. 44, no. 2, pp. 173-184, 2006.

[14] M. J. Syu and Y. H. Chen, "A study on the $\alpha$-amylase fermentation performed by Bacillus amyloliquefaciens," J. Chem. Eng., vol. 65, pp. 237-247, 1997.

[15] S. Mishra, S. B. Noronha, and G. K. Suraishkumar, "Increase in enzyme productivity by induced oxidative stress in Bacillus subtilis cultures and analysis of its mechanism using microarray data," Process Biochem., vol. 40, pp. 863-1870, 2005.

[16] D. R. Mendu, B. V. V. Ratnam, A. Purnima, and C. Ayyanna, "Affinity chromatography of $\alpha$-amylase from Bacillus licheniformis," Ensyme Microbiol. Technol., vol. 37, pp. 712-717, 2005.

[17] Z. Baysal, F. Uyar, and C. Aytekin, "Solid state fermentation for production of $\alpha$-amylase by a thermotolerant Bacillus subtilis from hot-spring water," Process Biochem., vol. 38, pp. 1665 - 1668, 2003. 
[18] J. Y. Park, T. Seyama, R. Shiroma, M. Ike, S. Srichuwong, K. Nagata, Y. Arai-Sanoh, M. Kondo, and K. Tokuyasu, "Efficient recovery of glucose and fructose via enzymatic saccharification of rice straw with soft carbohydrates," Biosci. Biotechnol. Biochem., vol. 73, no. 5, pp. 1072 - 1077, 2009.

[19] S. Narang and T. Satyanarayana, "Thermostable $\alpha$-amylase production by an extreme thermophile Bacillus thermooleovorans," Lett. Appl. Microbiol., vol. 32, pp. 31 - 35, 2001.

[20] D. Gangadharan, S. Sivaramakrishnan, K. M. Nampoothiri, and A. Pandey, "Solid culturing of Bacillus amyloliquefaciens for alpha amylase production," Food Tech. Biotechnol., vol. 44, no. 2, pp. 269-274, 2006.

[21] P. V. D. Aiyer, "Effect of C:N ratio on alpha amylase production by Bacillus licheniformis SPT 27," African J. Biotechnol., vol. 3, no. 10, pp. 519-522, 2004.

[22] S. Bhargav, B. P. Panda, M. Ali, and S. Javed, "Solid-state fermentation: An overview," Chem. Biochem. Eng. Q, vol. 22, pp. $49-70,2008$.

[23] S. Ramachandran, A. K. Patel, K. M. Nampoothiri, S. Chandran, G. Szakacs, C. R. Soccol, and A. Pandey, "Alpha amylase from a fungal culture grown on oil cakes and its properties," Brazil. Arch. Biol. Technol., vol. 47, pp. $309-317,2004$. 
